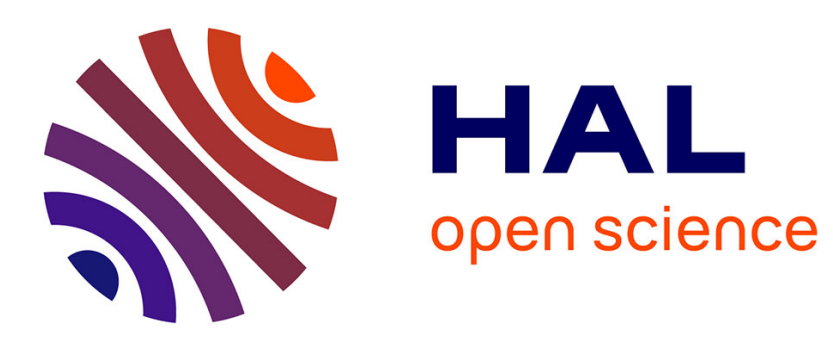

\title{
Securing the airway in critical care scenarios-questioning the fundamentals Author's reply
}

\author{
Samir Jaber, Audrey de Jong
}

\section{To cite this version:}

Samir Jaber, Audrey de Jong. Securing the airway in critical care scenarios-questioning the fundamentals Author's reply. Intensive Care Medicine, In press, 10.1007/s00134-021-06552-6 . hal-03412469

HAL Id: hal-03412469

https://hal.science/hal-03412469

Submitted on 3 Nov 2021

HAL is a multi-disciplinary open access archive for the deposit and dissemination of scientific research documents, whether they are published or not. The documents may come from teaching and research institutions in France or abroad, or from public or private research centers.
L'archive ouverte pluridisciplinaire HAL, est destinée au dépôt et à la diffusion de documents scientifiques de niveau recherche, publiés ou non, émanant des établissements d'enseignement et de recherche français ou étrangers, des laboratoires publics ou privés. 


\title{
Securing the airway in critical care scenarios-questioning the fundamentals Author's reply
}

\author{
Samir Jaber ${ }^{*}$ and Audrey De Jong
}

We thank Bhakta et al. for their letter [1] concerning our article [2]. We are glad that the authors of the letter appreciated that this multicentre randomized clinical trial is a pragmatic and important study.

As accurately stated by Bhakta et al. [1], it is important to emphasize that the success of intubation depends on multiple factors, including optimal anaesthesia and muscle relaxation. As it was a pragmatic study, the use of neuromuscular blockers and their dosing were left to the appreciation of the clinician, taking into account the recommendations of the Montpellier Intubation Protocol $[3,4]$. The large sample size of the STYLETO study [2] allowed that the use or not and the dosing of neuromuscular blockers were well-balanced between groups (Table 1 and Supplemental Table S4) [2]. We agree with the authors that the optimal dose of rocuronium in case of rapid sequence induction is $1.2 \mathrm{mg} / \mathrm{kg}$ of ideal body weight, as pointed out in the latest versions of the Montpellier Intubation Protocol $[3,4]$. In the same way as the use of neuromuscular blockers, Ketamine use for anaesthesia induction was also well-balanced between the two groups $(72.2 \%$ in the tracheal tube + Stylet group, and $65.5 \%$ in the tracheal tube alone, Supplemental Table S4) [2]. One of the main purposes of randomisation was therefore achieved for both neuromuscular blockers and ketamine use: balancing of confounding factors in order to create a control group that is as similar as possible to the treatment group.

Regarding the expertise of the operators, we disagree with the authors of the letter [1]. The number of expert

*Correspondence: s-jaber@chu-montpellier.fr

Department of Anesthesia and Intensive Care Unit, Regional University

Hospital of Montpellier, St-Eloi Hospital, University of Montpellier,

PhyMedExp, INSERM U1046, CNRS UMR, 9214 Montpellier Cedex 5, France operators was similar between the tracheal tube and Stylet and the tracheal tube alone groups, respectively $23 \%$ and $23.5 \%$, just as the number of intubations performed by the operators in the intensive care unit (ICU) (Table S3) [2].

As observed by Bhakta et al. [1], two serious adverse events (mediastinal and oesophageal injuries) occurred in the tracheal tube and Stylet group. However, similar adverse events were also reported in the group without Stylet, such as tracheal and laryngeal injuries (Table 2) [2].

Regarding the use of the Bougie in comparison to the Stylet, we agree with Bhakta et al. [1] that it remains to be evaluated in the ICU. The main objective of the STYLETO study was to assess the effect of a Stylet on successful first-attempt intubation in critically ill patients using a standard Macintosh laryngoscope [2]. The study [2] was powered to answer to the main objective, with a large sample size of 999 patients, and a design with high level of proof, i.e. a multicentre randomized controlled trial. Therefore, we do not agree with the conclusion of Bakhta et al. [1] that "advocating the universal use of a stylet for a first intubation attempts seems premature on the current evidence". We agree that these results cannot be applied to other settings, such as emergency departments, or intubation procedures performed with a video laryngoscope [5]. The appropriate conclusion is that the use of a Stylet for tracheal intubation in critically ill adult patients using a standard Macintosh laryngoscope resulted in significantly higher successful first-attempt intubation than the use of tracheal tube alone $(78.2 \%$ vs $71.5 \%)$. 


\section{Conflicts of interest}

SJ reports receiving consulting fees from Drager, Medtronic, Baxter, FreseniusXenios, and Fisher \& Paykel. ADJ reports receiving consulting fees from Medtronic.

\section{Ethics committee approval}

Not applicable.
2. Jaber S, Rollé A, Godet T, Terzi N, Riu B, Asfar P, Bourenne J, Ramin S, Lemiale V, Quenot JP, Guitton C, Prudhomme E, Quemeneur C, Blondonnet R, Biais M, Muller L, Ouattara A, Ferrandiere M, Saint-Léger P, Rimmelé T, Pottecher J, Chanques G, Belafia F, Chauveton C, Huguet H, Asehnoune K, Futier E, Azoulay E, Molinari N, De Jong A (2021) Effect of the use of an endotracheal tube and stylet versus an endotracheal tube alone on firstattempt intubation success: a multicentre, randomised clinical trial in 999 patients. Intensive Care Med 47:653-664

3. Monet C, De Jong A, Jaber S (2021) Intubation in the ICU. Anaesthe Crit Care Pain Med 40:100916

4. Jaber S, De Jong A (2021) Use of stylet and airway management procedure in critically ill patients. Author's reply. Intensive Care Med. https:// doi.org/10.1007/s00134-021-06518-8

5. De Jong A, Pouzeratte Y, Laplace A, Normanno M, Rollé A, Verzilli D, Perrigault PF, Colson P, Capdevila X, Molinari N, Jaber S (2021) Macintosh videolaryngoscope for intubation in the operating room: a comparative quality improvement project. Anesth Analg 132:524-535

\section{References}

1. Bhakta P, Walsh S, Reazaul Karim H, Mugawar M, O'Brien B (2021) Securing the airway in critical care scenarios - questioning the fundamentals. Intensive Care Med. https://doi.org/10.1007/s00134-021-06547-3 